\title{
Inosine Pranobex Enhances Human NK Cell Cytotoxicity in the Treatment of Acute Respiratory Viral Infections Including COVID-19
}

\author{
Jiří Beran* \\ Head Department for Tropical and Travel Medicine, Immunization Institute of Postgraduate Health Education in Prague, Czech \\ Republic
}

*Corresponding author: Jiří Beran, Head Department for Tropical and Travel Medicine and Immunization Institute of Postgraduate Health Education in Prague, Director Vaccination and Travel Medicine Centre Tylovo nábřeží 418/6, 50002 Hradec Králové, Czech Republic

\section{ARTICLE INFO}

Received: March 09, 2020

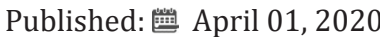

Citation: Jiří Beran. Inosine Pranobex Enhances Human NK Cell Cytotoxicity in the Treatment of Acute Respiratory Viral Infections Including COVID-19. Biomed J Sci \& Tech Res 26(5)-2020. BJSTR. MS.ID.004414.

Abbreviations: IP: Inosine Pranobex; NK: Natural Killers; SSPE: Subacute Sclerosing Panencephalitis; HSV: Herpes Simplex Virus; HPV: Human Papillomavirus; TCA: Tricarboxylic Acid

\begin{abstract}
The Inosine Pranobex (IP) by stimulating Natural Killers (NK) is effective in the treatment of acute viral respiratory infections and hopefully also against Covid-19. IP is a synthetic compound with immunomodulatory and antiviral properties. It is authorized since 1971 in more than 70 countries worldwide for the treatment of many different viral diseases. In one of the recent studies, the authors proved that the NK cells population increased within 90 min of IP receiving and by Day 5, the level was double. In another study, the authors showed that IP via metabolic activation influences NKG2D ligand induction, leading to increased NKG2D-dependent target cell immunogenicity. In the past, IP was used to treat measles and measles pneumonia. One of the very old studies was shown that IP treatment of measles was significantly better in the prevention of lethal course of measles infection. In a recent clinical study, we compared the efficacy in subjects with laboratory-confirmed acute respiratory viral infections. Time to resolution (in subgroups) of all influenza-like symptoms between treatment groups was statistically significant with faster clinical improvement in the IP group. The knowledge of IP antiviral activity can be used for the treatment of Covid-19 as an acute viral disease. In the elderly, who are immunosenescenced and for people with a significant chronic disease the standard dose can be $1 \mathrm{~g}$ ( 2 tablets)/4 times per day for 7-14 days or 2 days after symptoms resolution.
\end{abstract}

Keywords: Inosine Pranobex; Natural Killers; Acute Respiratory Viral Infection; Treatment; Covid-19

\section{Mini Review}

Clinical and immunological research which was performed during past 5 years can explain the very effective role of Inosine Pranobex (IP) and Natural Killers (NK) in treatment of the majority of viral infections hopefully also against Covid-19 as one of the currently spread acute viral respiratory infection. Inosine pranobex (IP), commonly known as inosine acedoben dimepranol, isoprinosine or methisoprinol, is a synthetic compound with immunomodulatory and antiviral properties. The drug was initially authorized in 1971. IP is currently marketed in more than 70 countries worldwide for the treatment of viral diseases, including subacute sclerosing panencephalitis (SSPE), herpes simplex virus (HSV) and varicella infections, human papillomavirus (HPV), cytomegalovirus and Epstein-Barr virus infections, acute viral respiratory infections, measles, and immunosuppressed states [1]. IP affects via NK almost all the viruses that replicate in the human body. As authors pointed out in their publication, studies with IP demonstrate that the immunomodulatory activity of IP is characterized by enhanced lymphocyte proliferation, cytokine production, and NK cell cytotoxicity [2]. In detail, all the immunomodulatory activity are described in the publication of Slíva [1]. 
In one of the recent studies [3], the authors proved that after IP administration was an early and durable rise in NK cells. For half the cohort, NK cells increased as a percentage of total peripheral blood lymphocytes within $1.5 \mathrm{~h}$ of receiving the IP. By Day 5, all but one of the volunteers displayed higher NK cell percentages, such elevation - effectively a doubling or greater - was maintained at the termination of the study. The IP induced populations were as replete in Granzyme A and Perforin as basal NK cells [3]. The authors of the study [2] show a more detailed influence of the IP on cellular level. They show that exposure of target cells to IP leads to increased expression of multiple NKG2D ligands. They found that IP causes an increase in intracellular concentration of purine nucleotides and tricarboxylic acid (TCA) cycle intermediates and NKG2D ligand induction. The degree of NKG2D ligand induction was functionally significant, leading to increased NKG2D-dependent target cell immunogenicity. These findings demonstrate that the immunomodulatory properties of IP are due to metabolic activation with NKG2D ligand induction [2]. Approximately 40 years ago when the measles vaccine was not available, IP was used to treat measles, resp. primary measles pneumonia. One of the very old studies was shown that IP treatment of measles was significantly better in the prevention of lethal course of measles infection (Table 1) [4]. Today, such a study cannot be repeated because most children are vaccinated and the number of primary measles pneumonia can be counted on the fingers of one hand in one country in a certain time period. Nevertheless, this information about the treatment of measles and primary measles pneumonia can be also supportive for use in the treatment of complicated cases of Covid-19.

Table 1: Analysis of 200 hospitalised children and half of them treated with IP for measles infection.

\begin{tabular}{|c|c|c|}
\hline & Isoprinosine & Placebo \\
\hline Lethal course of infection & 6 & 15 \\
\hline Non-Lethal course of infection & 94 & 85 \\
\hline Total & 100 & 179 \\
\hline
\end{tabular}

Note: IP treatment $100 \mathrm{mg} / \mathrm{kg} /$ weight is statistically significant $(0.05<\mathrm{p}<0.025)$ in prevention of lethal course of measles

The most frequent viral infection around the globe is an acute respiratory infection, which its severe form is responsible for approximately 3.9 million deaths per year and it is one of the leading causes of morbidity and mortality worldwide [5]. These numbers can increase significantly after the current uncontrolled spread of Covid-19. Acute respiratory infections are categorized as either upper or lower respiratory infections and are caused by wellrecognized viral pathogens, including but not limited to influenza virus (types A and B), parainfluenza virus, respiratory syncytial virus (RSV), metapneumovirus (types A and B), coronavirus, rhinovirus, enterovirus, reovirus, bocavirus, and adenovirus $[6,7]$. In view of the current Covid-19 pandemic is very important to mention also the results of the study we compared the efficacy and safety of IP with placebo in subjects with laboratory-confirmed acute respiratory viral infections in order to evaluate the clinical use of IP for the treatment of acute respiratory viral infections. The primary efficacy endpoint was a comparison between IP and placebo groups in terms of the time to resolution of all influenzalike symptoms present at baseline to none [8]. IP 500-mg tablets or placebo were self-administered by the subjects for 7 days ( 2 tablets orally 3 times daily). The first dose was taken immediately after randomization at the study site, and the remaining doses were to be self- administered at home. Doses were taken approximately $8 \mathrm{~h}$ apart but consistent with the subject's lifestyle, ie, scheduling of dosing did not disturb the subject's usual sleep patterns. The subjects were provided with kits containing (randomized) medication sufficient for 1 subject for 7 days of treatment [8].

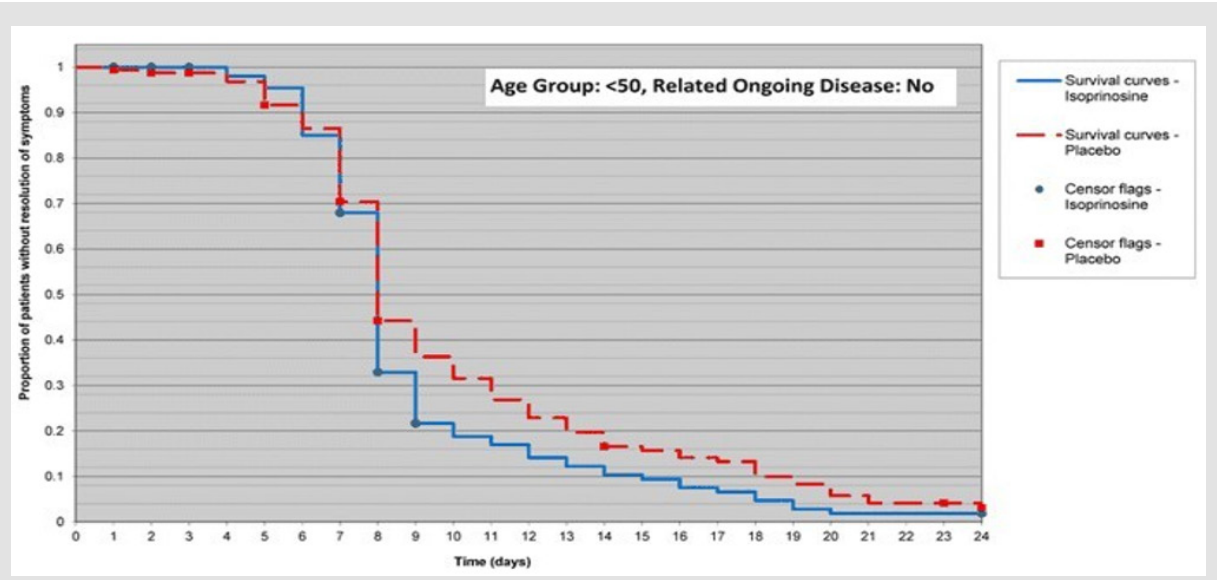

Figure 1: Faster improvement in subjects in the Inosine pranobex (IP) group compared with subjects in the placebo group. Note: Time to resolution was the total number of days from randomisation to the first instance at which all influenza-like symptoms had a score of 0 
In the subgroup analysis, for subjects, less than 50 years of age without related ongoing disease, the difference in time to resolution of all influenza-like symptoms between treatment groups was statistically significant $(p=0.050)$ and showed faster improvement in subjects in the IP group compared with subjects in the placebo group (Figure 1) [8]. The novel clinical and laboratory findings of IP activity can be in this context used as a treatment option (off-label in some countries) for at least some cases of infection during the current pandemic of Covid-19 with standard treatment schedule for young and otherwise healthy people $1 \mathrm{~g}$ ( 2 tablets)/3 times per day up to 50 tablets. In the elderly, who are immunosenescenced and for people with a significant chronic disease the standard dose can be increased to $1 \mathrm{~g}$ ( 2 tablets)/4 times per day for 7-14 days or 2 days after symptoms resolution. It is obvious that boosting phenotypically competent NK cells in healthy individuals supports the IP's indicated benefit in conditions associated with any acute viral respiratory infection and reinforces the potential for uplift where immune performance may be compromised $[3,8]$.

\section{References}

1. Sliva J, Pantzartzi CN, Votava M (2019) Inosine Pranobex: A Key Player in the Game Against a Wide Range of Viral Infections and Non-Infectious Diseases. Adv Ther 36(8): 1878-1905.

ISSN : 2574-1241

DOI: 10.26717/BJSTR.2020.26.004414

Jiří Beran. Biomed J Sci \& Tech Res

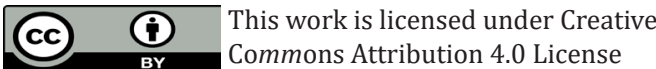

Submission Link: https://biomedres.us/submit-manuscript.php
2. Mc Carthy MT, Da Lin, Soga T, Adam J, O'Callaghan (2020) CA: Inosine pranobex enhances human NK cell cytotoxicity by inducing metabolic activation and NKG2D ligand expression. Eur J Immunol 50(1): 130-137.

3. Rumel Ahmed S, Newman AS, O'Daly J, Duffy S, Grafton G, et al. (2017) Inosine Acedoben Dimepranol Promotes an Early and Sustained Increase in the Natural Killer Cell Component of Circulating Lymphocytes: A Clinical Trial Supporting Anti-Viral Indications. Int Immunopharmacol 42: 108-114.

4. Gallais H, Kadio A, Odehouri K, Moreau J, Bertrand E (1981) Activity of Isoprinosine in tropical measles (a double blind study involving 200 patients). Bull Soc Pathol Exot Filiales 74(5): 553-561.

5. (2013) World Health Organization. Influenza: Brave call to action.

6. Osidak LV, Obraztsova EV (2012) The results of studying of inclusion of inosine pranobex into the therapy of acute respiratory viral infections in children [in Russian]. Healthc Prof 10.

7. Chavan RD, Kothari ST, Zunjarrao K, Chowdhary AS (2015) Surveillance of acute respiratory infections in Mumbai during 2011-12. Indian J Med Microbiol 33(1): 43-50

8. Beran J, Šalapová E, Špajdel M, on behalf of the Isoprinosine Study (EWO ISO-2014/1) Team (2016) Inosine pranobex is safe and effective for the treatment of subjects with confirmed acute respiratory viral infections: analysis and subgroup analysis from a Phase 4, randomised, placebo-controlled, double-blind study. BMC Infect Dis 16: 648.

$\begin{array}{ll}\text { BIOMEDICAL } & \text { Assets of Publishing with us } \\ \text { RESEARCHES } & \text { - Global archiving of articles } \\ & \text { - Immediate, unrestricted online access } \\ & \text { - Rigorous Peer Review Process } \\ & \end{array}$

